\title{
ECOLOGICAL DISTRIBUTION, MORPHOLOGICAL AND MOLECULAR CHARACTERIZATION OF ZYGOPHYLLACEAE FROM DIVERSE ECOLOGICAL ZONES OF BALOCHISTAN, PAKISTAN
}

\author{
AHMED, A. ${ }^{1 *}-$ HAMEED, A. $^{2}-$ SAEED, $S .^{1}$ \\ ${ }^{1}$ Department of Botany, University of Balochistan, Quetta 87300, Pakistan \\ (phone: +92-81-921-1264) \\ ${ }^{2}$ Nuclear Institutes for Agriculture and Biology (NIAB), Fasialabad 38000, Pakistan \\ ${ }^{*}$ Corresponding author \\ e-mail: aliaahmed_botany@yahoo.com \\ (Received 20 $0^{\text {th }}$ Nov 2019; accepted $30^{\text {th }}$ Jan 2020)
}

\begin{abstract}
The study was aimed to characterize and document the wild plants of Zygophyllaceae in arid and semiarid regions of Balochistan. The morphology, ecology and molecular characteristics and taxonomic implications of many taxa were subject to analysis. The field survey was carried out during 2017-18 in the diverse elevation zones of Balochistan selected due to the presence of the highest number of Zygophyllaceae in these regions. Morphological and molecular characterization was carried out by using, agglomerative hierarchical clustering and Principal Component Analysis. A total of 17 plants of Zygophyllaceae were documented from Sibi, Mashkaf, Noshki, Naal, Dalbandeen, Punjgur, Hingol National Park, Bella, Uthal and Quetta region. Commonly distributed taxa were Peganum hermala and Tribulus terrestris. Furthermore, seven species of Fagonia, five species of Tribulus and four species of Zygophyllum were also assessed. The present study documents and contributes detailed significant information of naturally occurring medicinal plants of Zygophyllaceae from diverse remote zones of Balochistan. It also provides a base line for identification of controversial taxa on morphological and molecular basis. Especially the data provided may further be utilized for novel drug development. Furthermore, the ecological distribution may be useful in management of conservation of endangered and endemic taxa.
\end{abstract}

Keywords: Fagonia, Tribulus, Zygophyllum, Peganum, arid and semi-arid zones, PCA, AHC

\section{Introduction}

Balochistan is the largest province comprising $44 \%$ of the total area of Pakistan. Geographical region comprised of arid to semi-arid structure ranging from cool temperate to coastal tropics. The diverse ecological conditions have an impact on the diversity of flora found. Local communities utilize wild plants as folk medicines in large amount. Selected areas are blessed by botanical diversity and endemism. Diverse taxa of the region include herbs, shrubs, and trees including evergreen Juniper forest. Aromatic, non-aromatic flowering and non-flowering plants contributes in more than sixteen hundred wild plant species. Total of 44 species are endemic to the Balochistan (Saeed et al., 2014).

The Zygophyllaceae consists of diverse habits of wild flora including succulents, herbs, undershrub, shrubs and small trees. The habitat of these plants is predominantly desert or saline areas of temperate and tropical regions around the globe (Beier et al., 2003; Bellstedt et al., 2008). Tribulus, Fagonia, Zygophyllum and Peganum considered being the main genera. Folk medicinal System is a precious resource, hence utilized as potent safe drugs (Hussain and Sher, 1998). Many members of the family are being used ethno medicinally for centuries in folk medicines. Taxa like Peganum hermala, Fagonia indica, F. ovalifolia, F. bruguieri, Tribulus terrestris, T. longipetalus etc traditionally used by local communities to cure fever, cough, inflammation of organs, gonorrhea, obesity, urinary tract infection (UTI) etc. 
(unpublished data). Many medicinal plants extract constituted various types of chemicals, each have a property to control a variety of biological and pharmacological activities such as antimicrobial, anti-parasitic, anti-diabetic, antioxidant, anti-inflammatory and anticholinesterase. These chemicals may have a combined effect in controlling various diseases (Rates, 2001; Houghton et al., 2007).

For proper identification and standardization of crude drugs, accurate anatomical and morphological description is necessary, and this description must take into account all the diagnostic features. The evaluation of crude drug involves a number of methods such as organoleptic, microscopic, chemical, physiological and biological. Organoleptic evaluation includes shape, size, odor, taste, texture, and color of crude drug along with external marking. On the basis of gross morphology, drugs may be grouped as leaves, bark, root, rhizome, and so forth. Microscopic features such as spines, trichomes, spores, and epidermal structures may be examined which are used as diagnostic features in the identification of plant drugs (Fransworth and Soejarto, 1988; Fazal et al., 2013). As the selected plants are medicinally important and utilized in folk medicine system, their authentication is essential on morphological and molecular basis that may be utilized for novel drug discovery as a future prospect.

During the past few decades, the theoretical framework of population genetics and empirical data gathered with the help of molecular genetic methods have been widely used in conservation biology. Given a haploid nature and a low frequency of genetic recombination, molecular markers of organelle DNA have long been used for phylogenetic reconstruction at various taxonomic levels, conservation genetics, and assessing the migratory routes of species (Nite-Kang and Yong, 2014; Yong and Nite-Kang, 2015).

Molecular marker system used to assess genetic variability within and among populations. Several marker systems were being used for genetic diversity analysis. Randomly Amplified Polymorphic DNA (RAPD) markers are appropriate for DNA fingerprinting of unknown sequences and they are rapid and easy to assess, (Kernodle et al., 1993). The Inter Simple Sequence Repeat (ISSR) did not need prior sequence and was less vulnerable (Adams et al., 2003). Universal Rice Primer (URP) markers were first time used by Kang et al. (2002). These are repeated chains that were extracted of genome bank of the rice of local Korea. URP markers with suitable PCR condition, produce high polymorphs. Additionally, it has been proved that these markers are useful tools for genetic analysis in between and within species (Rashmi et al., 2008; Abbas et al., 2015). Combined marker system used to assess genetic diversity within and among the population of different wild plants which were not sequenced earlier (Saeed et al., 2015, 2017).

In this view the present study was designed to provide comprehensive information about the medicinally important and highly controversial taxa of Zygophyllaceae used in folklore from different ecological zones of Balochistan, based on morphological and molecular characterization.

\section{Material and Methods}

\section{Study Sites}

The field survey was carried out during 2017-18 in various regions viz., Quetta valley, Sibi, Mashkaf, Noshki, Naal, Dalbandeen, Punjgur, Hingol National Park, Bella and Uthal. These areas of Balochistan were selected due to the presence of high number of taxa of Zygophyllaceae (Figure 1). 

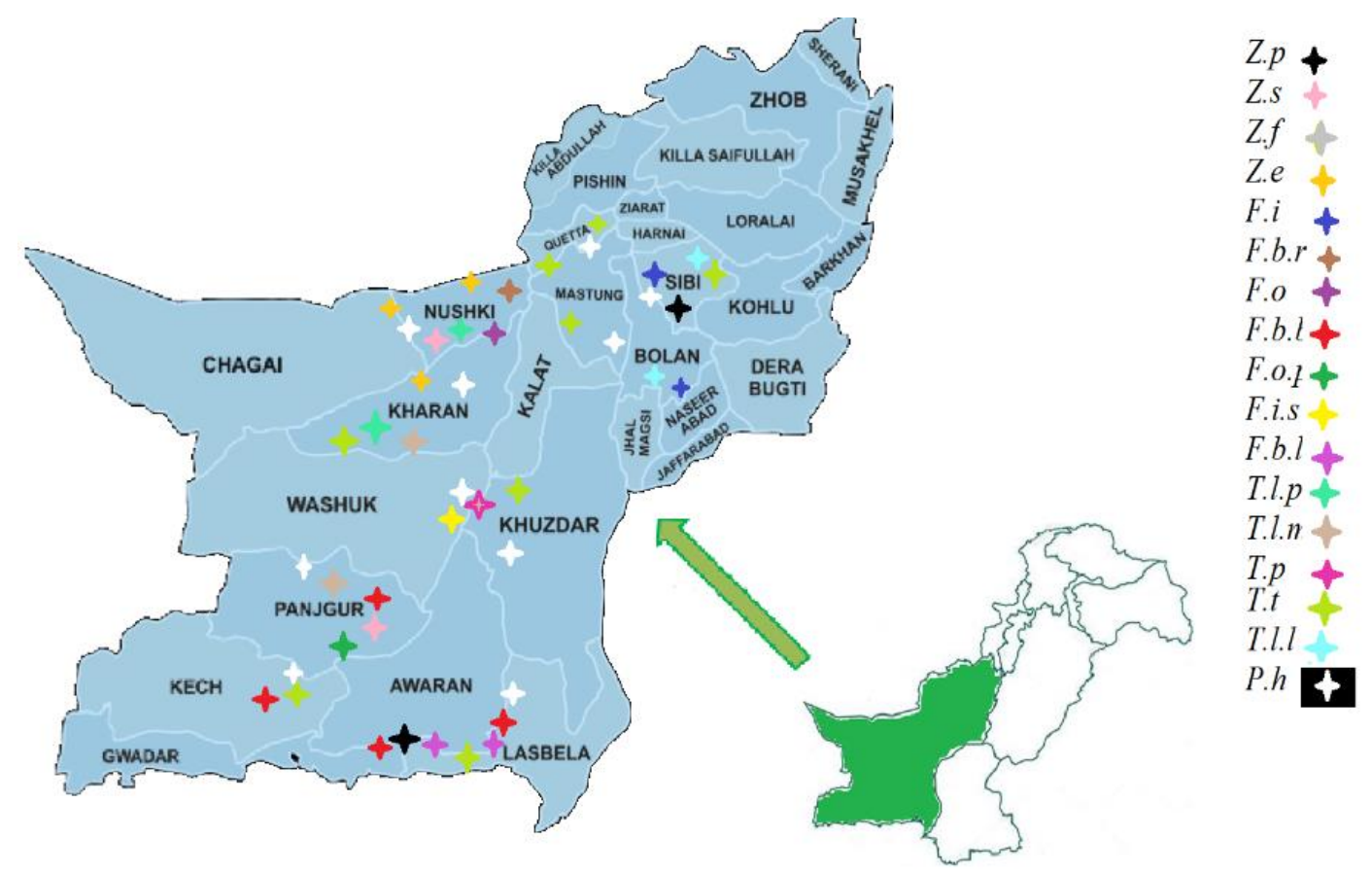

Figure 1. Map of Balochistan (Pakistan) illustrating the sampling site areas with geographical coordinates

\section{Morphological Analysis}

Total 58 characters were observed during the morphological analysis. Qualitative and Quantitative morphological characters were appraised and subjected to Principal Component Analysis (PCA) and Agglomerative Hierarchical Clustering (AHC).

\section{Molecular Analysis}

This study was carried out using three different marker systems namely, RAPD, ISSR and URP's (Table 1). Combined markers RAPD, ISSR and URP were used to amplify for cluster analysis.

\section{DNA Extraction}

Genomic DNA was isolated by using CTAB (Cetyl Trimethyl Ammonium Bromide) Doyle and Doyle (1987). Quantified on a spectrophotometer at $260 \mathrm{~nm}$ and Checked DNA Quality on $0.8 \%$ gel by electrophoreses.

\section{PCR Amplification}

PCR reaction for amplification was carried out. Total $20 \mu$ volume reaction was prepared. Enzynomics 2X TOPsimple DyeMIX-nTaq, Master Mix was used. PCR mixture contains $5 \mu 1$ Master Mix (2X), $0.4 \mu 1$ Primer $(5 \mathrm{pmol} / \mu \mathrm{l}), 4 \mu \mathrm{l}$ DNA template $(0.1 \mathrm{ng} / \mu \mathrm{l})$. PCR amplification was performed using thermal cycler (Applied Biosystems 96 well USA). For RAPD primers, PCR was performed with initial denaturation at $94^{\circ} \mathrm{C}$ for $4 \mathrm{~min}$, Denaturation $94^{\circ} \mathrm{C}$ for $4 \mathrm{~min}$ and then 36 cycles with annealing temperature $33^{\circ} \mathrm{C}$ for $1 \mathrm{~min}$, extension step at $72^{\circ} \mathrm{C}$ for 2 minutes. An additional extension step for 7 minutes at $72^{\circ} \mathrm{C}$ in the final cycle was also added. For 
URP primers, cycles increased to 40 . ISSR primers performed 40 cycles. The amplified products were checked by electrophoresis in $1.8 \%$ agarose gels. Gel stained with ethidium bromide $(0.5 \mu \mathrm{g} / \mathrm{ml})$ in $1 \mathrm{X}$ TAE buffer. The product was visualized by Gel documentation under UV light and the size of markers were estimated by comparing to the standard ladder (100 bp BIORON $0.2 \mathrm{mg} / \mathrm{ml}$ ) in the gel.

Table 1. List of primers includes name of primers, and sequence of the primers used in the study

\begin{tabular}{|c|c|c|}
\hline S. No. & Primer Name & Sequence (5'-3') \\
\hline \multicolumn{3}{|c|}{ RAPD } \\
\hline 1 & OPA-01 & CAGGCCCTTC \\
\hline 2 & OPA-02 & TGCCGAGCTG \\
\hline 3 & OPA-03 & AGTCAGCCAC \\
\hline 4 & OPA-04 & AATCGGGCTG \\
\hline 5 & OPA-07 & GAAACGGGTG \\
\hline 6 & OPA-09 & GGGTAACGCC \\
\hline 7 & OPC-19 & GTTGCCAGCC \\
\hline 8 & OPC-26 & CACGTTATCGCA \\
\hline 9 & OPD-13 & GGGGTGACGA \\
\hline 10 & OPD-20 & ACCCGGTCAC \\
\hline 11 & OPD-69 & CGCTCCAAAT \\
\hline 12 & OPF-21 & AGCAACAATC \\
\hline 13 & OPF-22 & AAGATCAAAGAC \\
\hline 14 & OPG-04 & AGCGTGTCTG \\
\hline 15 & OPG-09 & CTGACGTCAC \\
\hline 16 & OPG-13 & CTCTCCGCCA \\
\hline 17 & OPH-02 & TCGGACGTGA \\
\hline 18 & OPH-04 & GGAAGTCGCC \\
\hline 19 & OPP-03 & CTGATACGCC \\
\hline 20 & OPT-02 & GGAGAGACTC \\
\hline 21 & OPT-05 & GGGTTTGGCA \\
\hline 22 & OPU-03 & CTATGCCGAC \\
\hline 23 & OPW-04 & CAGAAGCGGA \\
\hline 24 & OPX-17 & GACACGGACC \\
\hline 25 & OPAJ-20 & ACACGTGGTC \\
\hline 26 & S-03 & AGCGGGGTCA \\
\hline 27 & S-05 & GGTCAACCCT \\
\hline 28 & S-11 & GAGGCGCTGC \\
\hline 29 & S-23 & CGGCCACCGT \\
\hline 30 & UBC-181 & ATGACGACGG \\
\hline 31 & UBC-194 & AGGACGTGCC \\
\hline 32 & UBC-733 & GGGAAGGGAG \\
\hline \multicolumn{3}{|c|}{ URPS } \\
\hline 01 & URP-25F & GATGTGTTCTTGGAGCCTGT \\
\hline 02 & URP-1F & ATCCAAGGTCCGAGACAACC \\
\hline 03 & URP-2R & CCCAGCAACTGATCGCACAC \\
\hline 04 & URP-17R & AATGTGGGCAAGCTGGTGGT \\
\hline \multicolumn{3}{|r|}{ 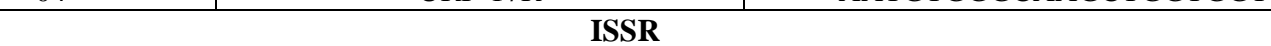 } \\
\hline 01 & INC-6 & CGCGATAGATAGATAGATA \\
\hline 02 & INC-7 & GACGATAGATAGATAGATA \\
\hline 03 & INC-8 & AGACAGACAGACAGACGC \\
\hline 04 & INC-14 & СТССТССТССТССТСТТ \\
\hline 05 & INC-16 & ТСТСТСТСТСТСТСТСА \\
\hline
\end{tabular}




\section{Gel Analysis by Software}

Then amplified products were checked by electrophoresis in $1.5 \%$ agarose gels in $1 \mathrm{X}$ TAE buffer. Further gel was stained in ethidium bromide. The product was visualized by Gel documentation system under UV light and the size of markers was estimated by 100-1500 bp DNA ladder (RTU) containing orange G \& xylene cyanol FF tracking dyes in the gel. Gel analysis was carried out by using UVI-Soft UVI-Band Map. Similarity coefficients Nie \& Li (Dice) were performed by UPGMA. Dendrogram generated based on homology.

\section{Results}

In this project seventeen wild species of Zygophyllaceae were reported from diverse and remote ecological zones of Balochistan including endemic taxa (Figure 2). Voucher specimen of all collected species was submitted in www.openherbarium.edu. Geographical coordinates of these plants at their existing habitats were recorded and the Phenology (flowering period) of the taxa was also recorded (Table 2).

Table 2. Geographical coordinates, soil type and phenology of selected Taxa of Zygophyllaceae

\begin{tabular}{|c|c|c|c|c|c|c|c|}
\hline S. No & Plant Name & $\begin{array}{l}\text { Plant } \\
\text { code }\end{array}$ & Voucher No. & Locality & \begin{tabular}{|c|}
$\begin{array}{c}\text { Elevation } \\
\text { (meter above } \\
\text { sea level) }\end{array}$ \\
\end{tabular} & Soil type & $\begin{array}{c}\text { Phenology } \\
\text { (Flowering } \\
\text { Period) } \\
\end{array}$ \\
\hline 1 & Z. propinquum & Z.p & QUETTA000208 & $\begin{array}{c}\text { Hingol National } \\
\text { Park, Mushkaf, Sibi }\end{array}$ & $100-350$ & \begin{tabular}{|c|} 
Sandy, common \\
carnonishius saline \\
sandy loam soil \\
\end{tabular} & March -April \\
\hline 2 & Z. simplex & Z.s & QUETTA000218 & Panjgur, Noshki & $950-990$ & Sandy Rocks & March -April \\
\hline 3 & Z. fabago & Z.f & QUETTA000090 & Quetta & $1650-1700$ & Sandy loam & July-Aug \\
\hline 4 & Z. eurypterum & Z.e & QUETTA000157 & $\begin{array}{c}\text { Noshki, Dalbandeen, } \\
\text { Kharan }\end{array}$ & $990-1000$ & Sandy rock & March-April \\
\hline 5 & F. indica & F.i & QUETTA000207 & Mushkaf, Sibi & $100-200$ & Sandy & Feb-Aug \\
\hline 6 & $\begin{array}{l}F . \text { bruguieri var } \\
\text { rechingeri }\end{array}$ & F.b.r & QUETTA000222 & Noshki (Stone) & $990-1000$ & Sandy rock & March-May \\
\hline 7 & $F$. oliveri & F.o & QUETTA000221 & Noshki (Janglat area) & 1000 & Sand & March-May \\
\hline 8 & $\begin{array}{c}\text { F. bruguieri var. } \\
\text { bruguieri }\end{array}$ & F.b.b & QUETTA000220 & \begin{tabular}{|c|} 
Panjgur, Uthal, \\
Hingol National \\
Park, Turbat
\end{tabular} & 970 & Sand & February-April \\
\hline 9 & $\begin{array}{l}\text { F. ovalifolia var. } \\
\text { pakistanica }\end{array}$ & F.o.p & QUETTA000219 & Panjgur & 980 & Sandy stones & March-April \\
\hline 10 & $\begin{array}{c}\text { F. indica var. } \\
\text { scheweinfurthii }\end{array}$ & F.i.s & QUETTA000223 & Naal & 1200 & Sandy Rock & $\begin{array}{c}\text { April- } \\
\text { September }\end{array}$ \\
\hline 11 & F. bruguieri var laxa & F.b.l & QUETTA000224 & $\begin{array}{l}\text { Uthal, Hingol } \\
\text { National Park }\end{array}$ & $0-150$ & Sandy Rock & February-April \\
\hline 12 & \begin{tabular}{|c|} 
T. longipetalus \\
subsp. pterophorus
\end{tabular} & T.1.p & QUETTA000215 & Noshki & 993 & Sandy rock & March-May \\
\hline 13 & $\begin{array}{c}\text { T. longipetalus } \\
\text { subsp. macropterus }\end{array}$ & T.1.m & QUETTA000216 & Panjgur, Kharan & 970 & Sand & February-May. \\
\hline 14 & T. pentandrus & T.p & QUETTA000217 & Naal & 1200 & Sandy Rock & $\begin{array}{c}\text { February- } \\
\text { August. }\end{array}$ \\
\hline 15 & T. terrestris & T.t & QUETTA000085 & $\begin{array}{c}\text { Bella, Punjgur, } \\
\text { Noshki, Sibi, Hingol } \\
\text { National Park, } \\
\text { Quetta } \\
\end{array}$ & $100-1650$ & Sand & April-October \\
\hline 16 & $\begin{array}{c}\text { T. longipetalus } \\
\text { subsp. longipetalus }\end{array}$ & T.1.1 & QUETTA000209 & Mushkaf, Sibi & $130-150$ & Sand & March-October \\
\hline 17 & P. hermala & P.h & QUETTA000002 & \begin{tabular}{|c|} 
Uthal, Khuzdar, \\
Bella, Punjgur, \\
Noshki, Kharan, \\
Sibi, Hingol National \\
Park, Naal, Quetta \\
\end{tabular} & $100-1700$ & Sand & April- August. \\
\hline
\end{tabular}




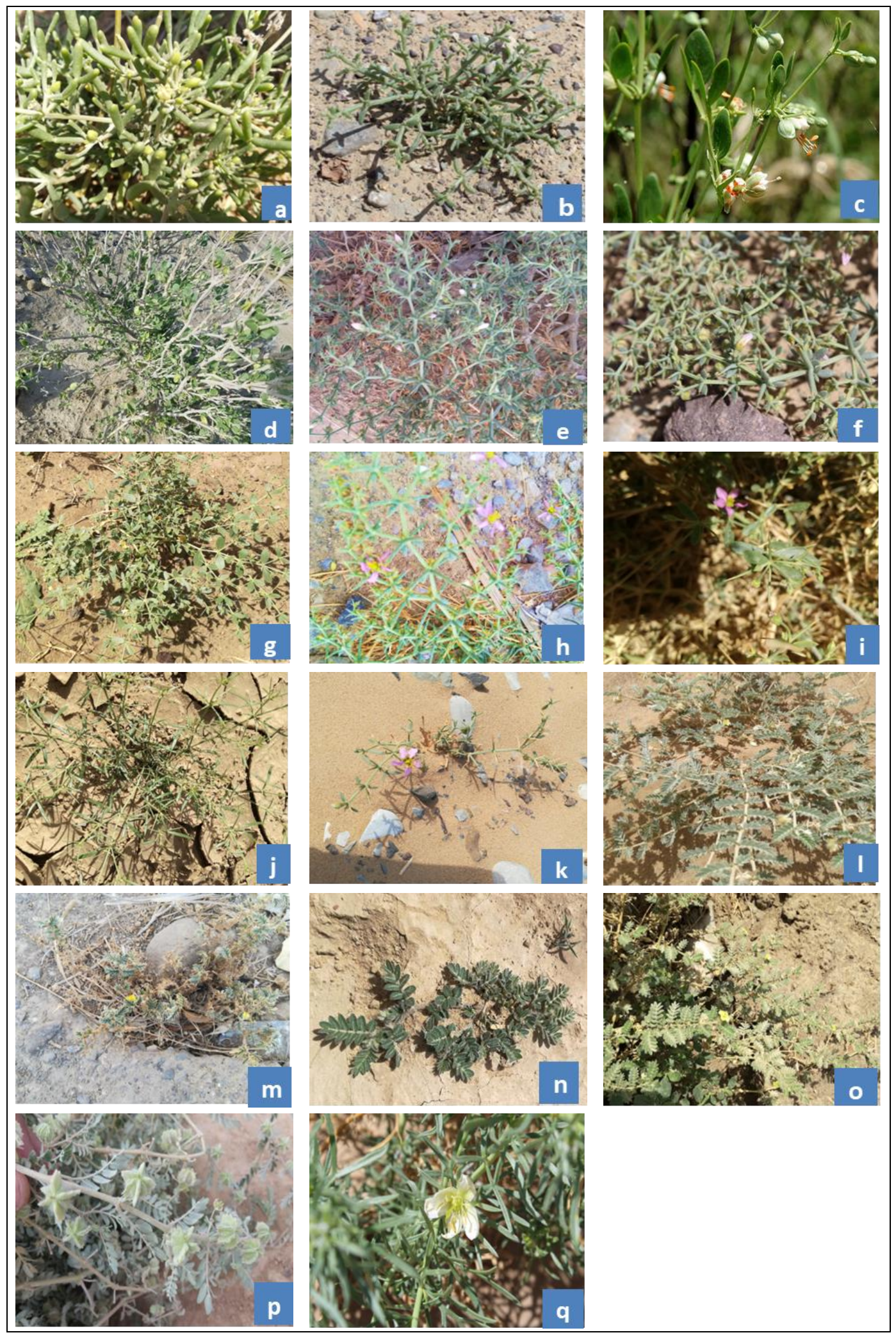

Figure 2. Plants at their habitat a) Z. propinquum, b) Z. simplex, c) Z. fabago, d) Z. eurypterum, e) F. indica, f) $F$. bruguieri var rechingeri, g) $F$. oliveri, h) $F$. bruguieri var. bruguieri, i) $F$. ovalifolia var. pakistanica, j) $F$. indica var. scheweinfurthii, k) $F$. bruguieri var laxa, I) T. longipetlus sub.sp. pterophorus, m) T. longipetalous sub.sp. macropterus, n) $T$. pentandrus, o) T. terrestris, p) T. longipetalus sub.sp longipetlus, q) P. hermala 


\section{Morphological Analyses}

Morphological evaluation of 17 taxa of Zygophyllaceae found in study area was carried out by total of fifty-nine morphological characters. Out of which thirty-one were qualitatively measured and twenty-eight were quantitative characters.

\section{Qualitative Analyses}

Life cycle

Studied taxa exhibited different life cycles. All the taxa of Tribulus were annual except the $T$. pentandrus was biannual. Perennial taxa were $P$. hermala, $Z$. fabago, $Z$. propinquum, Z. eurypterum and F. bruguieri var. laxa. F. indica var. schweinfurthii and $F$. indica were annual herbs all other taxa of Fagonia were Bi-annual.

\section{Plant nature}

Plant nature varied in all studied species of Zygophyllaceae. T. longipetalus subsp. pterophorus and T. longipetalus subsp. macropterus were prostrate-erect. T. longipetalus subsp. longipetalus, $T$. terrestris, $T$. pentandrus, F. bruguieri var. rechingeri, $F$. bruguieri var. bruguieri were prostrate in nature. $Z$. simplex was the only taxa having sub-erect plant nature. $F$. ovalifolia subsp. pakistanica was unique in nature i.e. Procumbent. $F$. indica var. schweinfurthii was ascending in nature. $F$. indica was decumbent and $F$. olivieri was sub-prostrate. All remaining were erect in nature.

\section{Plant surface}

Plant surface of $T$. longipetalus subsp. macropterus and $T$. pentandrus were densely hairy while $T$. longipetalus subsp. longipetalus, T. terrestris and Z. propinquum were sparsely hairy. $F$. bruguieri var. laxa was sparsely glandular whereas $F$. indica var. schweinfurthii, F. olivieri and F. bruguieri var bruguieri were glandular. Other taxa had glabrous plant surface.

\section{Hair shapes}

Hair shapes of T. longipetalus subsp. pterophorus, T. longipetalus subsp. macropterus, T. longipetalus subsp. longipetalus, T. terrestris, T. pentandrus, Z. propinquum and $F$. ovalifolia subsp. pakistanica were glandular.

\section{Trichome stalk}

In most of the taxa trichome stalk were absent while present only in all genera of Tribulus.

\section{Stem nature}

Nature of the stem varies from woody to herbaceous in selected taxa of Zygophyllaceae. Z. eurypterum was characterized in woody stem nature. All genera of Tribulus, $P$. hermala and $Z$. simplex were having herbaceous stem. The stem in all genera of Fagonia were woody at the base. 


\section{Stem outline shape}

Significant variations were found in stem outline shape of different taxa of Zygophyllaceae. T. terrestris, T. pentandrus, $P$. hermala and Z. propinquum were terete outline shape of stem. Z. fabago, Z. simplex and Z. eurypterum were striate. F. indica var. schweinfurthii and $F$. indica were terete and striate, while all other were quadrangular.

\section{Stipule}

Stipule was present in selected taxa of Zygophyllacae. Nature of stipule varies within the selected taxa. Stipule of T. pentandrus was bristles while other four genera of Tribulus and $Z$. eurypterum were foliaceous. Stipule nature of $P$. hermala was also bristles. $Z$. fabago, Z. propinquum and Z. simplex stipule were scarious and all the Fagonia species have spinescent stipule nature.

\section{Leaves/leaflets arrangement}

Leaves/leaflets arrangements were alternate in T. longipetalus subsp. pterophorus and $F$. indica var. schweinfurthii, whereas all other taxa were having opposite Leaves/leaflets arrangements.

\section{Leaf-bladeVeaflets}

Leaf-bladelleaflets of all the studied taxa of Tribulus were in paired while other taxa leaves were not paired.

\section{Leaf structure}

Variation was found in leaf structure of studied taxa. Leave of T. longipetalus subsp. pterophorus was paripinnat abruptly. Leave structure of $T$. longipetalus subsp. macropterus, T. longipetalus subsp. longipetalus, T. terrestris, T. pentandrus, $Z$. propinquum and Z. fabago were bifoliate. P. hermala and Z. eurypterum leaves were found simple. Z. simplex leaves succulent. F. bruguieri var. laxa leaves was trifoliate below and unifoliate above. All other taxa of Fagonia were had unifoliate leaf structure.

\section{Leaf petiole}

Leaf petiole showed variation among all selected taxa. Z. fabago, Z. propinquum, Z. eurypterum, F. ovalifolia subsp. pakistanica, F. bruguieri var. bruguieri, F. bruguieri var. laxa, $F$. indica var. schweinfurthii, $F$. indica and $F$. olivieri were petiolate. $T$. terrestris was sub-sessile while other taxa were sessile.

\section{Leafleaflet shape}

Leafleaflet shape also showed variation in all studied taxa. T. terrestris had ovate shape. T. longipetalus subsp. pterophorus, T. longipetalus subsp. macropterus, T. longipetalus subsp. longipetalus, T. pentandrus and Z. simplex shape were oblong. $Z$. propinquum was semi-cylindrical. $P$. hermala, $F$. bruguieri var. rechingeri, $F$. olivieri and $F$. bruguieri var. bruguieri were found in lanceolate shape. $F$. indica was ovoid, $F$. indica var. schweinfurthii was trifoliate, F. bruguieri var. laxa was linear lanceolate, and $F$. ovalifolia subsp. pakistanica was oblanceolate shape leaflets. 


\section{Leaf apex}

Leaf apex of $P$. hermala, $F$. indica var schweinfurthii and all taxa of Tribulus were acute. Z. fabago was oval apex. Z. propinquum and Z. simplex had obtuse apex. $Z$. eurypterum was found with spathulate, $F$. ovalifolia sub sp pakistanica was minutely mucronate. F. bruguieri var. rechingeri, F. bruguieri var. bruguieri, F. bruguieri var. laxa, $F$. indica and $F$. olivieri had mucronate apex.

\section{Sepal shape}

Shape of sepal of $F$. bruguieri var. rechingeri, $F$. bruguieri var. laxa and all species of Tribulus were lanceolate. $P$. hermala had linear sepal shape. $Z$. simplex was elliptic-oblong, $F$. olivieri was oblong. Whereas ovate sepal shape were found in $F$. indica, $F$. indica var. schweinfurthii, F. bruguieri var. bruguieri, F. ovalifolia subsp. pakistanica, Z. propinquum, Z. fabago and Z. eurypterum.

Sepal apex

Sepal apex was obtuse in Z. fabago and Z. propinquum, retuse in Z. eurypterum and acute in all remaining taxa.

\section{Sepal surface}

Sepal surface varies from glabrous to hairy. Sepal surface of $T$. longipetalus subsp. longipetalus was sparsely hairy. F. ovalifolia subsp. pakistanica, F. indica and $F$. olivieri had glandular sepal surface. T. longipetalus subsp. pterophorus, T. longipetalous subsp. macropterus, $T$. terrestris, $T$. pentandrus and $F$. indica var. schweinfurthii were having hairy sepal surface. While all other remaining taxa sepal were having glabrous surface.

\section{Sepal and petal persistence at fruit maturity}

Sepal in T. longipetalus subsp. pterophorus, T. longipetalus subsp. macropterus, T. longipetalus subsp. longipetalus, $T$. terrestris, $T$. pentandrus, $P$. hermala, $Z$. propinquum, Z. simplex, F. bruguieri var. rechingeri, F. bruguieri var. laxa and $F$. indica were persistent at the time of maturity. While in other taxa it was not persistent. Petals in all the studied taxa were not persistence at the time of fruit maturity.

\section{Petal shape}

Petal shape varies in these studied taxa. Obovate shape of petal was found in T. longipetalus subsp. pterophorus, T. longipetalus subsp. macropterus, T. longipetalus subsp. longipetalus, T. terrestris, Z. fabago, Z. eurypterum, F. ovalifolia subsp. pakistanica and $F$. indica var. schweinfurthii. T. pentandrus and $P$. hermala were oblong. $Z$. propinquum, Z. simplex, $F$. bruguieri var. rechingeri, $F$. bruguieri var. bruguieri, $F$. bruguieri var. laxa, $F$. indica and $F$. olivieri were spathulate.

\section{Petal colour}

Petal colour of all studied taxa showed variation. Petals of $P$. hermala, $Z$. propinquum and Z. simplex were yellowish white. Petal of $Z$. fabago was yellowish above orange at the base and $Z$. eurypterum was pale white. $F$. ovalifolia subsp. pakistanica and $F$. bruguieri var bruguieri were light pink in colour. F. bruguieri var. rechingeri was 
purple, $F$. bruguieri var. laxa was pale pink $F$. indica var. schweinfurthii pinkish purple and $F$. olivieri was pinkish white. Petals of all species of Tribulus were yellow in colour.

\section{Petal apex}

Retuse petal apex was found in Z. fabago. In Z. propinquum it was reported spathulate/margin serrate. Z. simplex was having serrate margin apex. The apex of petal T. longipetalus subsp. pterophorus, T. longipetalus subsp. macropterus, T. longipetalus subsp. longipetalus and T. terrestris were clawed. While in remaining taxa obtuse petal apex were found.

Ovary surface

Ovary surface was hairy in all selected species of Tribulus and as well as all selected species of Fagonia. While the surface glabrous in $P$. hermala and all selected species of Zygophyllum.

\section{Fruit type}

Fruit type of T. longipetalus subsp. pterophorus, T. longipetalus subsp. macropterus, $T$. longipetalus subsp. longipetalus and $T$. terrestris were schizocarpic. Fruit of Z. eurypterum was capsule oblong-sherical. Loculicidal capsule type of fruits was found in all the other remaining taxa.

\section{Fruit surface}

Fruit surface in $P$. hermala, Z. fabago, Z. propinquum and Z. eurypterum were glabrous. Z. simplex fruit surface was regulose. While all the other studied fruits type surface was Hairy to sparsely hairy.

\section{Fruit shape}

Fruit shapes vary in all selected studied taxa of Zygophyllacae. Shape of fruits in all species of Fagonia was pyramidate and not winged. Z. eurypterum was oblong-spherical and winged. Z. simplex fruit shape was oblong and not winged. Z. propinquum fruit was oblong pyramidate and not winged. Z. fabago was oblong-cylindric and not winged. Fruit shape of $P$. hermala was found trigonous and not winged. T. terrestris was also not winged and sub spherical. All other four species were winged and discoid.

\section{Seed shape}

Seed shape in all species of Tribulus and P. hermala were triangular. Z. eurypterum seed shape was reniform. Z. fabago, $Z$. propinquum and $Z$. simplex was oblong/compressed. Seed shape of $F$. indica var. schweinfurthii, F. indica and F. olivieri was broadly oblong. While oblong shape type of seeds were reported in three species of Fagoina i.e F. ovalifolia subsp. pakistanica, F. bruguieri var. bruguieri and $F$. bruguieri var. rechingeri. However seeds of $F$. bruguieri var. laxa were obovoid.

\section{Quantitative Analysis of Morphological Characters}

Morphological characterization was also performed on the basis twenty-eight quantitative characters in seventeen species of Zygophyllaceae. Quantitative characters were further subjected to analyses through Principle component analyses (PCA). 


\section{Principle Component Analyses (PCA)}

\section{Eigenvalues}

Out of 16 principal components (PCs), three viz. PC-1, PC-II, PC-III, PC-IV, PC-V and PC-VI had Eigen values $>1$ and contributed for $89.41 \%$ of total cumulative variability among different species (Table 3). The contribution of PC-I towards variability was highest $(35.96 \%)$, PC-II contributed (15.42\%), PC-III showed (13.72\%) variability, PC-IV gives (13.28\%), PC-V and PC-VI (6.05\% and 4.92\%) variability, respectively.

Table 3. Eigenvalues of Principle component analyses

\begin{tabular}{c|c|c|c|c|c|c}
\hline & F1 & F2 & F3 & F4 & F5 & F6 \\
\hline Eigenvalue & 10.069 & 4.319 & 3.843 & 3.719 & 1.707 & 1.379 \\
Variability (\%) & 35.960 & 15.424 & 13.725 & 13.281 & 6.095 & 4.924 \\
Cumulative \% & 35.960 & 51.384 & 65.109 & 78.390 & 84.485 & 89.409 \\
\hline
\end{tabular}

The PC-I showed 17 positive factor loadings (Figure 3) for Plant length, Petiole, Flower pedicle, Sepal length, Sepal width, Petal length, Petal width, Stamens number, Filament length, Style number, Style length, Stem internode, leaf length, leaf width, Fruit length, Fruit width, Fruit wings size, Fruit pedicel, Seed length, Seed width. PC-II indicated 15 positive factor loading for stipule width, Leaf-bladelleaflets no, flower pedicle, sepal length, Petal length, Petal width, Sepal No, Stamens number, Style number, Fruit width, Fruit wings size, Mericarp edge no, Fruit pedicel, Seed length. Quantitative characters which contributed 17 positive factor loadings towards PC-III were Plant length, Stipule width, Leaf-bladelleaflets no, Petiole, Sepal width, Petal No, Filament length, Style number, Stem internode, leaf width, Fruit length, Fruit width, Fruit wings size, Mericarp edge no, Number of fruit locules, Seed Length, Seed width. Plant length, Stipule width, Leaf-bladelleaflets no. leaflet petiole size, Petiole size, Sepal length, Petal length, Petal No, Sepal No, Stamens number, Filament length, Style number, Style length, Stem internode, leaf length, leaf width, Mericarp edge no, Number of fruit locules, Fruit pedicel were contributed 20 positive factor loadings towards PC-IV. 19 positive factor loadings towards PC-V were Plant length, Stipule length, Leaf-bladelleaflets no, leaflet petiole size, Petiole size, Flower pedicle, Sepal length, Sepal width, Petal width, Petal No, Sepal No, Filament length, Style length, Stem internode, leaf width, Fruit length, Fruit width, Fruit wings size, Mericarp edge no., and PC-VI included 17 positive factor loadings Plant length, Stipule length, Leafbladelleaflets no, leaflet petiole size, Petiole size, Flower pedicle, Sepal length, Petal length, Petal width, Stamens number, Style number, Fruit length, Fruit width, Number of fruit locules, Fruit pedicel, Seed size Length, Seed width.

\section{Cluster Analysis}

Clustering of studied taxa based on quantitative characters only is presented in (Figure 4). Cluster analysis grouped all taxa into 3 clusters which are further divided as Cluster-I comprised T.l.p, Cluster-II comprised of 15 taxa which are further divided into sub clusters a \& b. Cluster a comprised of P.h and Z.s. Cluster b further divided into c \& d. Cluster c comprised of Z.e. Cluser d have two more groups e and f. Cluster e comprised of T.t. Z.p. Z.f. T.1.m and T.1.1. while cluster $\mathrm{f}$ comprised of all Fagonia species. Cluster-III comprised of T.p. 


$$
-2456-
$$

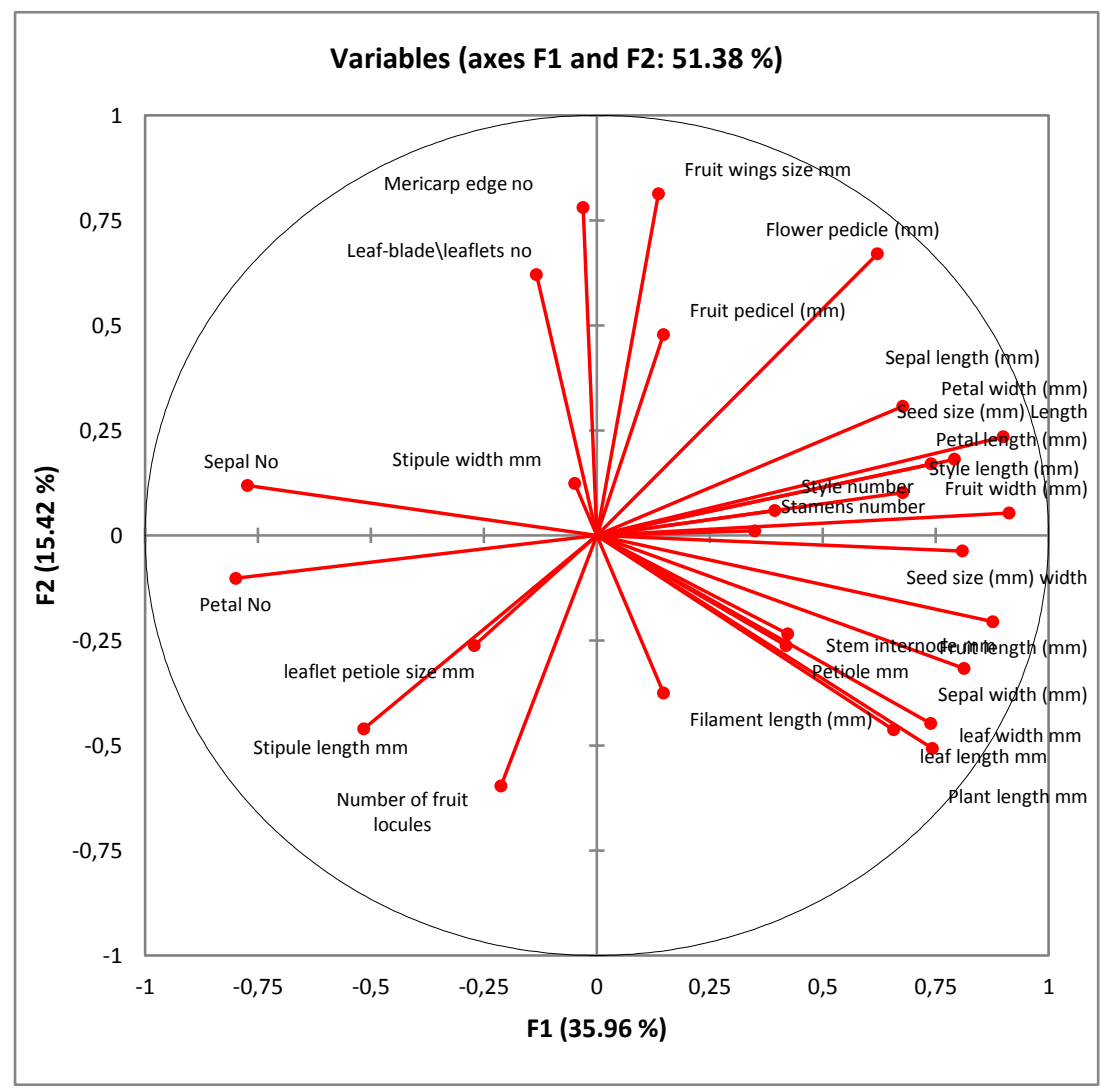

Figure 3. Correlations chart of 17 taxa of Zygophyllaceae plotted according to the first two principal components, obtained from morphological and quantitative traits

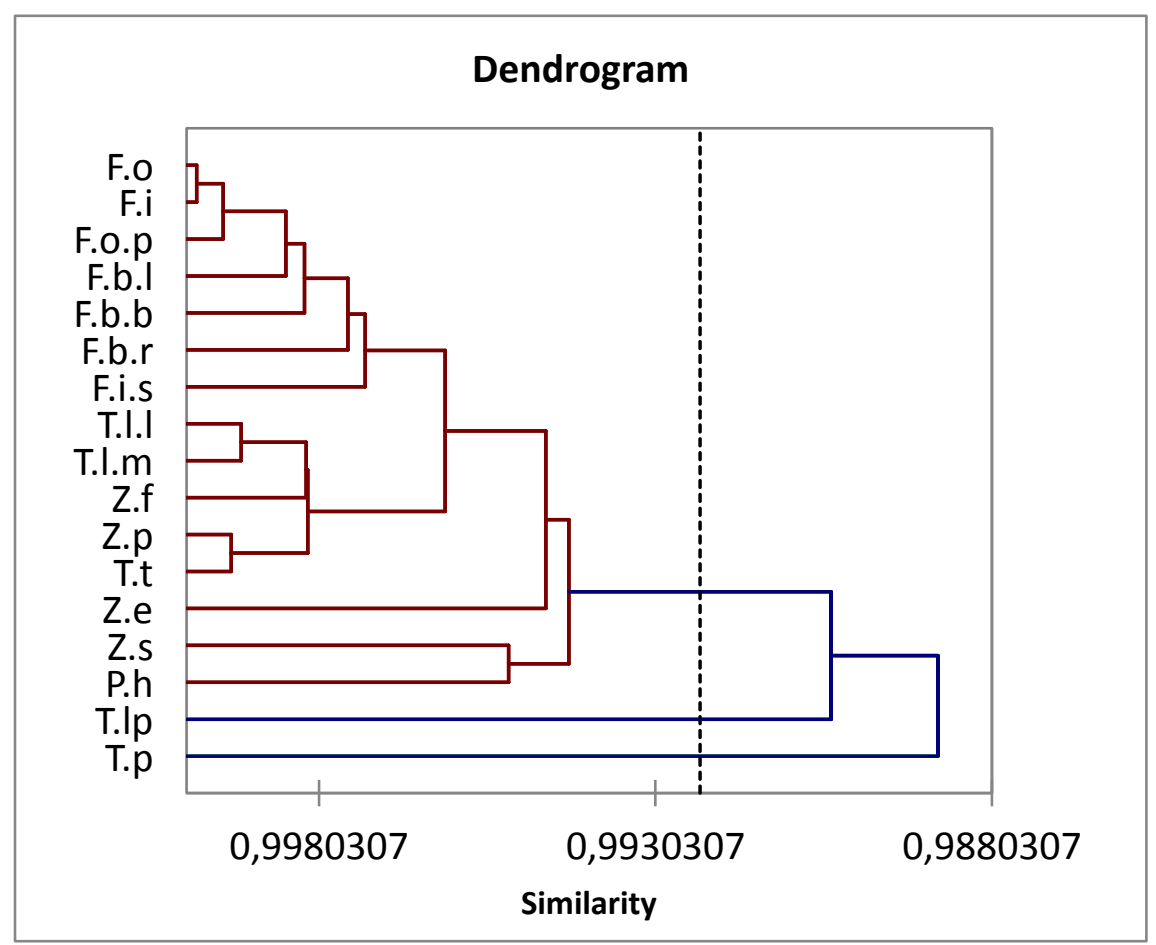

Figure 4. Tree diagram based on 28 quantitative characters in all selected taxa of Zygophyllaceae 


\section{Molecular Characterization}

Using different molecular markers may target different regions of genome and could help in removing errors for the detection of polymorphism. Out of forty-one tested primers, thirty two RAPD and five ISSR revealed polymorphism, and exhibited reproducible bands among all selected taxa of Zygophyllaceae. The URP's did not give amplification in selected taxa. These taxa were not characterized earlier by different markers combination so this study would give the amended pattern of genetic variation.

Dendrogram based on molecular data grouped all genera into three main clusters A, B and C (Figure 5). Cluster A grouped into four sub-clusters a,b,c,d. Cluster a comprised of three species i.e T. longipetalus subsp. longipetalus, T. longipetalus subsp. pterophorus and T. longipetalus subsp. macropterus. Cluster b comprised of four species i.e $P$. hermala, Z. simplex, Z. propinquum and Z. fabago. Cluster c comprised of F. olivieri, F. bruguieri var. rechingeri, F. bruguieri var. bruguieri. Cluster comprised of $T$. terrestris and $T$. pentandrus. Cluster B having sub-clusters $\mathrm{f}$ and e contained $Z$. eurypterum, $F$. indica, and $F$. indica var. schweinfurthii while on cluster $C F$. bruguieri var. laxa collected from Uthal (Zero point) and Hingol National Park both plants were identified with same species showing interspecific diversity that may be due to change in elevation.

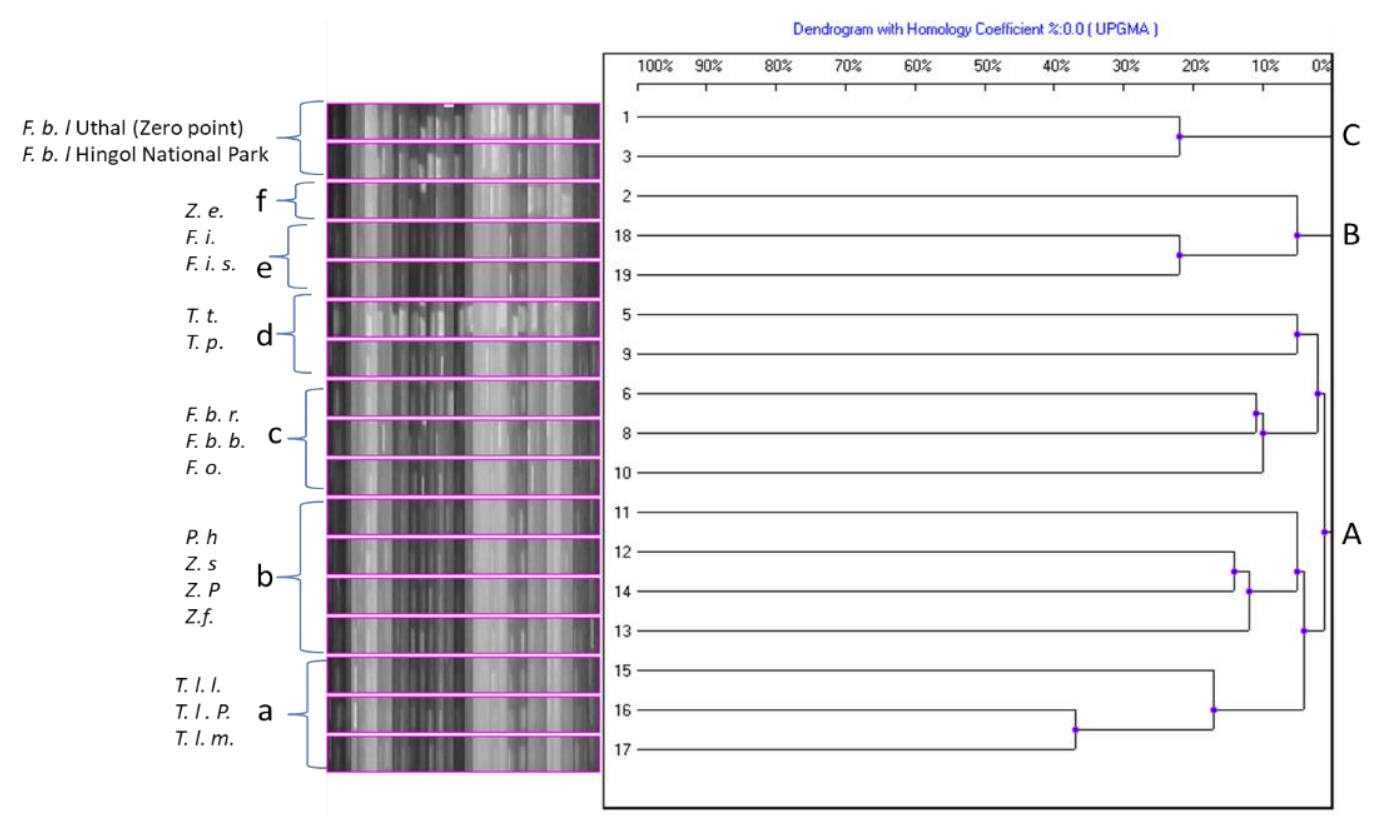

Figure 5. Cluster analysis UPGMA based on Homology Coefficient among taxa of Zygophyllaceae generated by combined tested markers

\section{Discussion}

\section{Ecological Distribution}

The species of Zygophyllaceae are widely distributed in scattered populations usually at diverse ecological zones from low to high elevations in Balochistan Pakistan. Earlier reported by Ghafoor (1974) that the plants are widespread in tropical, subtropical and warm temperate, often in drier areas and represented by 8 genera and 22 species. The present study revealed that $P$. hermala is widely distributed in all studied 
sites. From high-elevation to low-elevation zones, High elevation includes Quetta, Naal, Noshki, Low elevation includes Uthal, Hingol National Park, Mushkaf, Sibi. Environmental conditions play a key role in determining the distribution and functional distinctiveness of the species occupying a particular region (Ricklefs and Latham, 1992; Noman et al., 2012). Previously, few ethnobotanical and phytochemical studies of Zygophyllaceae were reported from Balochistan by Tareen et al. (2010), Perveen and Qaiser (2008), Zaidi and Crow (2005) and Manzoor et al. (2017). F. ovalifolia subsp. pakistanica is the Endemic species to Pakistan collected from Panjgur (Ghafoor, 1974). $F$. bruguieri was earlier reported from Johan and Kalat area of Balochistan by Goodman and Ghafoor (1992) whereas in present study three sub.species of $F$. bruguieri i.e. $F$. bruguieri var. rechingeri from Noshki sandy Rocks, F. bruguieri var. bruguieri were collected from Panjgur, F. bruguieri var. laxa were found from Hingol National Park and Uthal. F. indica var. schweinfurthii were collected from Naal. F. indica were collected from Mushkaf earlier reported in plant biodiversity of Dureji in southern Balochistan Province by Perveen and Qaiser (2008). F. olivieri were collected from Noshki, Near Janglat area, T. terrestris were collected from Quetta, Mushkaf, Lasbella and Noshki earlier Goodman and Ghafoor (1992) reported from Kalat and Khuzdar. T. longipetalus subsp. pterophorus were collected from Noshki. T. longipetalus subsp. macropterus from Panjgur, T. longipetalus subsp. longipetalus from Sibi and Mushkaf, T. pentandrus were collected from Naal area. Z. fabago were found from Quetta earlier also reported by Zaidi and Crow (2005) from Quetta. Z. eurypterum from Dalbandeen and Noshki Goodman and Ghafoor (1992) earlier reported from Mastung, Naal and Kharan. Z. simplex collected from Punjgur, Naal and Noshki. Z. propinquum were found in Hingol National Park and Mushkaf earlier work has been done on $Z$. propinquum from Dureji in Southern Balochistan by Perveen and Qaiser (2008). Manzoor et al. (2017) also collected Z. propinquum from Hub District Balochistan. It was observed that the studied sites most dominated plants were succulents, often xerophytic and spiny as the area were mostly deserted. The areas have dry and warm climatic conditions, with low rate of precipitations.

\section{Morphological Characterization}

Morphological characters play an important role identification and documentation of the taxa. Earlier different studies were conducted explaining morphological identification of different taxa. Pollen morphology of the family has also been examined by Perveen and Qaiser (2006). Sheahan and Cutler (1993) investigated the vegetative anatomy of 37 species in 19 genera of Zygophyllaceae. In present study based on 57 morphological characters were recorded to study the interspecific relationships between taxa present in Balochistan, Pakistan. Plants of Zygophyllaceae reported earlier for its great medicinal importance so the morphological characterization leads towards the validation of taxa used in folk medicines. The results of cluster and principal component analysis revealed that all collected species of Fagonia form a well-distinguished group earlier also reported by Kadry (2012). Fagonia species indicated the F.o and F.i closely related and clustered with F.o.p. F.b.l, F.b.r, F.i.s. Tribulus genus was also reported from the region. Previously El-Hadidi $(1975,1977)$ classified the species of Tribulus. Mohamed (2006) studied seed morphology, proteins and Iso-enzymes in Tribulus. Kadry (2012) also characterized different species of Tribulus. In present study T.p clustered separately. Its closed group was T.l.p. while T.l.l and T.l.m were clusterd together. Its closed group was T.t. Van Zyl (2000) presented morphological analysis of 
the genus Zygophyllum in South Africa. Kadry (2012) also characterized different species of Zygophyllum. Z.p. grouped with Z.f, Z.e grouped separately, may be because of its diverse habit, plant height and woody stem. Z.s grouped with P.h. In some previous reports, Peganum was placed in a distinct family (Takhtajan, 1969; El Hadidi, 1975). However, Takhtajan (1980) and El Hadidi and Fayed (1995) placed it in Zygophyllaceae. Kadry (2012) grouped Peganum with species of Zygophyllaceae as in present study. Shamso et al. (2013) concluded Zygophyllum and Fagonia linked in one group based on many characters.

\section{Molecular Characterization}

The molecular analysis confirmed the characterization of different genus of Zygophyllaceae. Earlier characterizations with in different genera of Zygophyllacae have been reported from many regions of the world. Al-Arjany et al. (2014) worked on molecular diversity among three genera of Zygophyllaceae they displayed the genetic relationships between Zygophyllum, Tribulus and Fagonia species. Their work is in agreement with the present work here we also included Peganum with these three genera. All species of Fagonia has different pattern as they give amplification on very different pattern. To the knowledge of the authors no earlier work has been reported on the characterization of Fagoina species. Bakatoushi and Ahmed (2017) represented the genetic diversity in different wild populations of Peganum from desert of Egypt. Molecular analysis of present data of Fagonia exhibited no amplification in two species by the selected markers that may be due to varying base pair patterns. Similar findings were earlier reported by Al-arjany et al. (2014). Thus these two species need to be studied with additional diverse molecular markers. As the $F$. ovalifolia var. pakistanica is the endemic taxa of the region no earlier report has been found. No molecular characterization data on Peganum has been reported earlier from the region. Patil et al. (2014) characterized three species of Tribulus. Hammad and Qari (2010) worked on twelve populations of Zygophyllum and explained the genetic diversity. Wu et al. (2015) characterized different species of Zygophyllaceae. Few reports also explained the molecular characterization of Zygophyllaceae by Godoy-Bürki et al. (2018) and Kadry (2012). Finding of present study is in agreement with earlier reported work. Molecular characterization plays an important role in characterization of taxa at inter specific and infraspecific level. As these important plants used in folk medicines their authentication is very important. Furthermore, molecular characterization for evaluating genetic diversity has widely been used in conservation biology.

\section{Conclusion and Recommendations}

The selected zones of Balochistan have diverse distribution of different genera of Zygophyllaceae. These plants are well adapted in suitable habitats and soil types of these regions. Enormous morphological and molecular markers provide a better understanding in authentication of some controversial taxa that could further be exploited for a novel drug discovery. Furthermore, the unsustainable utilization of these taxa may cause a serious decline. It is thus recommended that conservation strategies must be implemented including cultivation techniques of theses significant medicinal plants to fulfill the needs of local and International herbal market. 
Acknowledgements. This research project was supported by Higher Education Commission under Startup Research Grant Program (No. 21-1978/SRGP/R\&D/HEC/2018).

\section{REFERENCES}

[1] Abbas, G., Hameed, A., Rizwan, M., Ahsan, M., Asghar, M. J., Iqbal, N. (2015): Genetic Confirmation of Mungbean (Vignaradiata) and Mashbean (Vignamungo) Interspecific Recombinants using Molecular Markers. - Front. Plant Sci. 6: 1107.

[2] Adams, P. A., Schwarzbach, A. E., Naresh, P. R. (2003): The concordance of terpenoid, ISSR and RAPD markers, and ITS sequence data sets among genotypes: an example from Juniperus. - Bioch. Sys. and Eco. 31: 375-387.

[3] Al-Arjany, K. M., Bukhari, N. A. W., Ibrahim, M. M. (2014): Molecular diversity among three genera of Zygophyllaceae. - Conference Proceedings ICABEE. 1-6.

[4] Beier, B. A., Chase, M. W., Thulin, M. (2003): Phylogenetic relationships and taxomony of subfamily Zygophylloideae (Zygophyllaceae) based on molecular and morphological data. - Plant Systematics and Evolution 240: 11-39.

[5] Bellstedt, D. U., Van Zyl, L., Marais, E. M., Bytebier, B. L. G., De Villiers, C. A., Makwarela, A. M., Dreyer, L. L. (2008): Phylogenetic relationships, character evolution and biogeography of southern African members of genus Zygophyllum (Zygophyllaceae) based on three plastid regions. - Molecular Phylogenetics and Evolution 47: 932-949.

[6] Doyle, J. J., Doyle, J. L. (1987): A rapid DNA isolation procedure for small quantities of fresh leaf material. - Phytochemical bulletin 19: 11-15.

[7] El-Bakatoushi, R., Ahmed, D. G. A. (2017): Evaluation of genetic diversity in wild populations of Peganum harmala L., a medicinal plant. - Journal of Genetic Engineering and Biotechnology 16(1): 143-151.

[8] El-Hadidi, M. N. (1975): Zygophyllaceae in Africa. - Boissieria 24: 317-323.

[9] El-Hadidi, M. N. (1977): Two new Zygophyllum species from Arabia. - Publication of Cairo University Herbarium 7/8: 327-331.

[10] El-Hadidi, M. N., Fayed, A. A. (1995): Materials for an Excursion Flora of Egypt. Taeckholmia 15: 40-53.

[11] Fazal, H., Ahmad, N., Abbasi, B. H. (2013): Identification, Characterization, and Palynology of High-Valued Medicinal Plants. - The Scientific World Journal Vol. 2013, 9 pages.

[12] Fransworth, N. R., Soejarto, D. D. (1988): Global importance of medicinal plants. - In: Akerele, O., Heywood, V., Synge, H. (eds.) The Conservation of Medicinal Plants. Proceedings of an international consultation, pp. 25-51.

[13] Ghafoor, A. (1974): Zygophyllaceae. - In: Nasir, E., Ali, S. I. (eds.) Flora of Pakistan. Pakistan: Karachi University, 1-35.

[14] Godoy-Bürki, A. C., Acosta, J. M., Aagesen, L. (2018): Phylogenetic relationships within the New World subfamily Larreoideae (Zygophyllaceae) confirm polyphyly of the disjunct genus Bulnesia. - Systematics and Biodiversity 16(5): 453-468.

[15] Goodman, S. M., Ghafoor, A. (1992): The Ethnobotany of southern Balochistan, Pakistan, with particular reference to medicinal plants. - Publication/Field museum of natural history.

[16] Hammad, I., Qari, S. H. (2010): Genetic diversity among Zygophyllum (Zygophyllaceae) populations based on RAPD analysis. - Genetics and Molecular Research 9(4): 24122420.

[17] Houghton, P., Howes, M. J., Lee, C., Steventon, G. (2007): Uses and abuses of in vitro tests in ethnopharmacology: visualizing an elephant. - Journal of Ethnopharmacology 110(3): 391-400. 
[18] Hussain, F., Sher, H. (1998): In-situ protection management and conservation of some important medicinal plants of District Swat. Proc. National Seminar on Medicinal Plants of Pakistan. - PGRI, NARC-IUCN Islamabad December 2-3.

[19] Kadry, N. A. K. (2012): A numerical taxonomic study of the family Zygophyllaceae from Egypt. - Acta Botanica Brasilica 26(1): 165-180.

[20] Kang, H. W., Park, D. S., Park, Y. J., You, C. H., Lee, B. M., Eun, M. Y., Go, S. J. (2002): Printing of diverse genomes using PCR with universal rice primers generated from repetitive sequence of Korean weedy rice. - Mol. Cells. 13(2): 72-81.

[21] Kernodle, S. P., Cannon, R. E., Scandalios, J. G. (1993): Concentration of primer and template qualitatively affects product in random amplified polymorphic DNA-PCR. Biotechniques 14: 362-364.

[22] Manzoor, S., Hameed, A., Khan, M. A., Gul, B. (2017): Seed germination ecology of a medicinal halophyte Zygophyllum propinquum: responses to abiotic factors. - Flora 233: 163-170.

[23] Mohammed, A. H. (2006): Taxonomic Significance of Seed Proteins and Iso-enzymes in Tribulus (Zygophyllaceae). - International Journal of Agriculture \& Biology 8(5): 573575.

[24] Nite-Kang, F., Yong, J. N. (2014): The chemistry and biological activities of natural products from Northern African plant families: from Aloaceae to Cupressaceae. - RSC Advances 106(4): 61975-61991.

[25] Noman, A., Hameed, M., Ali, Q., Aqeel, M. (2012): Foliar tissue architectural diversity among three species of genus Hibiscus for better adaptability under industrial environment. - International Journal of Environmental Sciences 2(4): 2212-2222.

[26] Patil, B., Harisha, C. R., Parmar, N., Save, A. (2014): Variants of Tribulus species - a scientific study through DNA RAPD molecular characterization. - Indian Journal of Pharmaceutical and Biological Research 2(4): 15-19.

[27] Perveen, A., Qaiser, M. (2008): Pollen flora of Pakistan-XLIX. Zygophyllaceae. Pakistan Journal of Botany 38(2): 225-232.

[28] Rashmi, A., Sharma, V., Lalit, L. (2008): Molecular characterization of Chaetomium species using URP-PCR. - Genetics and Molecular Bio. 4: 946-943.

[29] Rates, S. M. K. (2001): Plants as source of drugs. - Toxicon 39(5): 603-613.

[30] Ricklefs, R. E., Latham, R. E. (1992): Intercontinental correlation of geographical ranges suggests stasis in ecological traits of relict genera of temperate perennial herbs. American Naturalist 139: 1305-1321.

[31] Saeed, S., Barozai, M. Y. K., Ahmed, A., Shah, S. H. (2014): Impact of altitude on soil physical and chemical properties in Sra Ghurgai (Takatu mountain range) Quetta, Balochistan. - International Journal of Scientific \& Engineering Research 5(3): 730-735.

[32] Saeed, S., Barozai, M. Y. K., Ahmed, A., Tareen, R. B., Ali, G. M., Shehzad, S., Begum, S. (2015): Genetic diversity of Ephedra procera from high altitudes of Quetta valley, Balochistan using RAPD and ISSR. - Pak. J. Weed Sci. Res. 21(2): 163-172.

[33] Saeed, S., Barozai, M. Y. K., Ahmed, A., Tareen, R. B., Begum, S., Ali, G. M. (2017): Impact of Ecological Diversity On Genetic And Phytochemical Variation Injuniperus Excelsa From High Elevation Zones Of Quetta Valley, Pakistan. - Pak. J. Bot. 49(1): 201-206.

[34] Shamso, M., Rabei, S., Hamdy, R. (2013): Identification keys and numerical studies of Zygophyllaceae (S. Str.) and allied families in Egypt. - Assiut University Journal of Botany 42(2): 79-106.

[35] Sheahan, M. C., Cutler, D. F. (1993): Contributions of vegetative anatomy to the systematics of Zygophyllaceae R.Br. - Botanical Journal of the Linnean Society 113(3): 227-262.

[36] Takhtajan, A. (1969): Flowering plants: origin and dispersal. - Edinburgh, Oliver and Boyd. 
[37] Takhtajan, A. (1980): Outline of the classification of the flowering plants (Magnoliophyta). - Botanical Review 46: 225-359.

[38] Tareen, R. B., Bibi, T., Khan, M. A., Ahmad, M., Zafar, M., Hina, S. (2010): Indigenous knowledge of folk medicine by the women of Kalat and Khuzdar regions of Balochistan, Pakistan. - Pakistan Journal of Botany 42(3): 1465-1485.

[39] Van Zyl, L. (2000): A Systematic Revision of Zygophyllum in the Southern African Region. - Ph.D. thesis, University of Stellenbosch.

[40] Wu, S. D., Lin, L., Li, H. L., Yu, S. X., Zhang, L. J., Wang, W. (2015): Evolution of Asian Interior Arid-Zone Biota: Evidence from the Diversification of Asian Zygophyllum (Zygophyllaceae). - PLoS ONE 10(9): e0138697.

[41] Yong, J. N., Nite-Kang, F. (2015): The chemistry and biological activities of natural products from Northern African plant families: from Ebenaceae to Solanaceae. - RSC Advances 34(5): 26580-26595.

[42] Zaidi, M. A., Crow, S. A. Jr. (2005): Biologically active traditional medicinal herbs from Balochistan, Pakistan. - Journal of Ethnopharmacology 96: 331-334. 